УДК 332.122:339.92

Міхель Р.В., к.е.н., доцент

Mikhel R. PhD in Economics, Associate Professor https://orcid.org/0000-0001-8204-7600

\title{
ОЦІНКА ТРАНСКОРДОННОЇ СПЕЦІАЛІЗАЦІЇ ПРИКОРДОННИХ ОБЛАСТЕЙ УКРАЇНИ
}

\author{
Львівський національний університет імені Івана Франка
}

\begin{abstract}
Прикордонне співробітництво є явищем глобального масштабу і є ключовим елементом політики Європейського Союзу щодо своїх сусідів. Воно підтримує сталий розвиток вздовж зовнішніх кордонів $С$, допомагає зменшити диспропорції у рівні життя населення та вирішити спільні проблеми суміжних регіонів по обидва боки кордону. Роль транскордонного співробітництва у регіональному розвитку визначається його здатністю мобілізувати та ефективно використовувати наявний потенціал прикордонних районів та активізувати ресурси сусідніх прикордонних регіонів для пошуку рішення спільних проблем та сприяння співпраці у транскордонних регіонах.

У статті проаналізовано стан прикордонної спеціалізації областей України, що межують 3 державами-членами ЄС. Забезпечення ефективного використання можливостей транскордонного співробітництва для регіонального розвитку можливе лише при систематичному підході до організації управлінського впливу на процеси такої співпраці. Дуже важливо враховувати специфіку та індивідуальні особливості кожного прикордонного регіону. Для оцінки коефіцієнта прикордонній спеціалізації областей України автором запропоновано дослідити досліджено чотири сфери: інвестиційну, зовнішню торгівлю, туризм, міграційну сферу. На основі проведеного аналізу визначено області із найбільшим коефіцієнтом прикордонної спеціалізації та із найменшим. Результати розрахунку дозволили виявити для кожної області напрямки взаємодій $з$ найбільш високим ступенем прикордонній спеціалізації, а також виокремили слабкі сфери реалізації прикордонної спеціалізації. Проаналізовано динаміку коефіцієнта прикордонної спеціалізації досліджуваних областей упродовж останнього десятиліття та доведено важливість транскордонного співробітництва для прикордонних областей України, що межують з державами-членами EC.
\end{abstract}

Ключові слова: прикордонне співробітництво, прикордонні регіони, ЄС, зовнішня торгівля, туризм, іноземні інвестииії, міграція.

\section{ASSESSMENT OF CROSS-BORDER SPECIALIZATION OF BORDER REGIONS OF UKRAINE}

\author{
Lviv National Ivan Franko University
}

Annotation. Cross-border cooperation is phenomenon of global scale and it is a key element of the European Union's policy towards its neighbours. It supports sustainable development along the EU's external borders, helps to reduce disparities in living standards and to address common problems across those borders.. The role of the cross-border cooperation in regional development is determined by its ability to mobilize and effectively use the existing potential of border areas and activate the resources of neighbouring border regions to find the solution to common problems and promote cooperation within cross-border regions.

The article analyses the state of cross-border specialization of regions of Ukraine that have border with the EU member states. Ensuring the effective use of cross-border cooperation opportunities for regional development is possible only with a systematic approach to the organization of managerial influence on the processes of such cooperation. It is very important to take into account the specifics and individual features of each cross-border region. To assess the coefficient of cross-border specialization of Ukrainian cross-border regions four areas were studied: investment, foreign trade, tourism, and migration. Based on the analysis, the areas with the highest coefficient of border specialization and with the lowest were identified. The results of the calculation allowed us to identify areas of interaction with the highest degree of cross-border specialization. The author also analyses the dynamics of the coefficient of border specialization of the studied regions during the last decade and proves the importance of cross-border cooperation for the border regions of Ukraine that have the common border with the EU member states 

migration

Key words: cross-border cooperation, border regions, EU, foreign trade, tourism, foreign investments,

Постановка проблеми у загальному вигляді i ïi зв'язок 3 важливими науковими та практичними завданнями. Прикордонна співпраця є однією із форм більш загального явища, міжрегіональної співпраці, i розглядається як засіб для триваючих процесів регіоналізації. Підвищена проникність кордонів відбивається на інституційному та функціональному положенні прикордонних регіонів, і таким чином вони забезпечують своєрідний полігон для транскордонної регіоналізації. Прикордонний регіон України з СС є одним із таких грунтів, де потенційні процеси регіоналізації, що сприяють транскордонному співробітництву, впроваджуються за допомогою просторових домовленостей, які варіюють від великих багатонаціональних домовленостей, таких як Причорноморський регіон, до дуже малих, місцевих регіонів, які знаходяться поруч з пунктами пропуску кордону.

Транскордонне співробітництво (ТКС) $є$ ключовим елементом політики Європейського Союзу (СС) щодо своїх сусідів. Воно підтримує сталий розвиток вздовж зовнішніх кордонів СС, сприяє зменшенню відмінностей у рівні життя та вирішенню загальних проблем через ці кордони. 3 моменту розширення ЄС у 2004 та 2007 роках було запроваджено різні режими двосторонньої співпраці між новими країнами-членами ЄС та країнами, що об’єднуються під Європейською політикою сусідства, зокрема Україною. Вони прагнуть підтримувати існуючі зв'язки у сферах людських контактів, культурних обмінів, торгівлі та сезонної міграції. У цьому контексті роль ТКС в регіональному розвитку визначається його здатністю мобілізувати та ефективно використовувати наявний потенціал прикордонних районів та об'єднувати ресурси прикордонних регіонів сусідніх країн для пошуку вирішення загальних проблем та сприяння співпраці в межах транскордонні регіони.

Аналіз останніх досліджень, у яких започатковано вирішення проблеми. Питанням дослідження прикордонного співробітництва займалися такі дослідники, як Дж. Андерсон [1], Й. Блаттер [2], М. Буфон [3], Д.-Ж. Бут [4], А. Ван дер Веен [4], Ф. Дуран [5], А. Дековіль [5], Н. Жук [6], Н. Межевич [6, 7], Я. Маркус [8], Г. Ніпенберг [8] та інші. Серед українських вчених-економічнім прикордонне співробітництво України з СС досліджували 3. Варналій [9], С. Давиденко [10], О. Зарічна [11], В. Кравців [12], I. Кравченко [13], О. Кузьмін [13], Н. Кухарська [14], Н. Мікула [15, 16] та інші.

Однак, у працях присвячених співробітництву прикордонний областей України з країнами $\mathrm{CC}$, питання оцінки стану ефективності діяльності такої співпраці $\epsilon$ недостатньо вивченим.

Цілі статті. 3 огляду на це, метою статті буде спроба здійснити оцінку ефективності прикордонної співпраці чотирьох областей України (Волинської, Закарпатської, Львівської та Чернівецької), що межують із країнам-членами СС.

Виклад основного матеріалу дослідження 3 повним обгрунтуванням отриманих наукових результатів. Забезпечення ефективного використання можливостей прикордонного співробітництва для регіонального розвитку можливо тільки при системному підході до організації управлінського впливу на процеси такого співробітництва 3 урахуванням їх специфіки та особливостей окремих прикордонних регіонів. Цим визначається необхідність дослідження сучасної практики транскордонного співробітництва. Для кількісної оцінки значущості прикордонного співробітництва в загальній системі міжрегіональних зв'язків Н. Межевич та Н. Жук пропонують оцінити таку характеристику, як прикордонна спеціалізація окремих напрямків міжрегіональних взаємодії [8, с. 40-41]. Для кількісної оцінки рівня прикордонної спеціалізації міжрегіональних взаємодій пропонується ввести коефіцієнт 
прикордонній спеціалізації, який дає можливість охарактеризувати роль суміжної країни в сукупності транскордонних міжрегіональних взаємодій прикордонних областей України по виділеним сферам.

До таких сфер відносимо:

1. Інвестиційну взаємодію (коефіцієнт прикордонної спеціалізації іноземних інвестицій, який характеризує інвестиційну активність суміжної країни в економіці прикордонного регіону):

$$
\text { IІпс }=\frac{\text { IIк }}{\text { II }} \text { де }(1.1)
$$

ІІпс - коефіцієнт прикордонної спеціалізації іноземних інвестицій; ІІк - обсяг іноземних інвестицій суміжної країни в економіку області України, млн дол. США; II - загальний обсяг іноземних інвестицій в економіку області України, млн дол. США.

2. Зовнішню торгівлю (коефіцієнт прикордонної спеціалізації експорту/імпорту - характеризує зовнішньоторговельну активність між прикордонним регіоном і суміжної країною):

$$
\text { ЗТЕпс }=\frac{\text { Ек }}{\mathrm{E}} \text { де }(1.2)
$$

ЗТЕпс - коефіцієнт прикордонної спеціалізації експорту; Ек - обсяг експорту області України в суміжну країну, млн дол. США; Е - загальний обсяг імпорту області України, млн дол. США.

$$
\text { ЗТІпс }=\frac{\text { Ік }}{\mathrm{I}} \text { де }(1.3)
$$

ЗТІпс - коефіцієнт прикордонної спеціалізації імпорту; Ік - обсяг імпорту області України з суміжної країни, млн дол. США; I - загальний обсяг імпорту області України, млн дол. США.

3. Туризм (коефіцієнт прикордонної спеціалізації туристичного обміну - характеризує туристичну активність між прикордонним регіоном і суміжної країною. Може також розраховуватися окремо для вхідного i вихідного туристичних потоків):

$$
\text { ТОпс }=\frac{\text { ТОк }}{\text { Тор }} \text { де }(1.4)
$$

ТОпс - коефіцієнт прикордонної спеціалізації туристичного обміну, ТОк - обсяг туристичного обміну з суміжної країною, кількість осіб; ТОр -загальний обсяг туристичного обміну прикордонним регіону.

4. Міждержавну міграцію (коефіцієнт прикордонної спеціалізації міграційного обміну - характеризує міграційну активність між прикордонним регіоном і суміжної країною. Може також розраховуватися окремо для вхідного і вихідного міграційного потоку):

$$
\text { ММпс }=\frac{\text { ММк }}{\mathrm{MMp}} \text { де }(1.5)
$$

ММпс - коефіцієнт прикордонної спеціалізації міждержавного міграційного обміну, ММк - обсяг міграційного обміну з суміжної країною, кількість осіб; ММр загальний обсяг міждержавного міграційного обміну прикордонним регіону.

Отримані значення коефіцієнтів прикордонної спеціалізації зовнішніх міжрегіональних взаємодій прикордонних областей України за напрямками взаємодій можуть служити основою для виявлення напрямків 3 підвищеним ступенем прикордонної спеціалізації, а також маркером для більш ретельного аналізу окремих напрямків взаємодії. Інтегральна оцінка коефіцієнта прикордонної спеціалізації по окремому регіону розраховується як середнє значення усіх зазначених коефіцієнтів прикордонної спеціалізації за певний період.

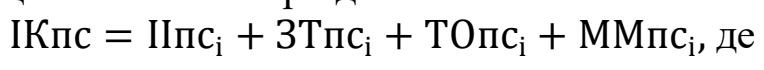


ІКпс - інтегральний коефіцієнт в рік $i$, ІІпс $\mathrm{i}_{\mathrm{i}}$ - коефіцієнт прикордонної спеціалізації іноземних інвестицій в рік $i$, 3Тпс $c_{\mathrm{i}}$ - коефіцієнт прикордонної

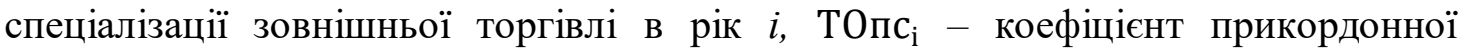
спеціалізації туристичного обміну в рік $i$, ММпс $_{\mathrm{i}}-$ коефіцієнт прикордонної спеціалізації міграційного обміну в рік $i$.

Слід зазначити, що через відсутність статистичних даних транскордонного співробітництва дане дослідження не може бути виконане в повному об'ємі. Так, зокрема інвестиційна взаємодія розглядається в односторонньому порядку, 3 точки зору іноземних інвестицій суміжної країни в економіку прикордонного регіону. Також було б цікаво дослідити економічну активність суб' єктів господарювання за участю іноземного капіталу суміжної держави, однак збір такої статистики відсутній. Цікаво було б розглянути й сферу освіти, зокрема статистику обміну студентами, практику подвійних дипломів і т. п.

Також варто зазначити, що в туристичному напрямку вихідним показником $є$ кількість туристів, обслугованих туроператорами та турагентами. Потрібно врахувати, що частка самостійного туризму за останні роки різко зросла, але статистика, на жаль, не надає даних для кількісної оцінки цього явища.

Запропонований метод оцінки передбачає певне спрощення, однак при практичній відсутності кількісних оцінок процесів прикордонного співробітництва, спробуємо виявити значимість прикордонного співробітництва для прикордонних регіонів і конкретизувати сфери взаємодії, в яких процеси прикордонної співпраці відрізняються особливою інтенсивністю. Таким чином, на основі зазначеної методології, для проведення оцінки прикордонної спеціалізації транскордонної міжрегіональної взаємодії було обрано три прикордонні області України, що межують з країнами СС Волинську, Закарпатську та Львівську.

Отже, опираючись на наявну статистичну інформацію, проведемо порівняльний аналіз прикордонної спеціалізації зазначених областей у 2019 році (табл. 1.).

Таблиця 1

Коефіцієнти прикордонної спеціалізації зовнішніх міжрегіональних взаємодій прикордонних областей України з державами-членами СС за напрямками взаємодії у

$$
2019 \text { році }
$$

\begin{tabular}{|c|c|c|c|c|c|c|c|c|c|}
\hline \multirow{2}{*}{ Область } & \multirow{2}{*}{$\begin{array}{l}\text { Країна- } \\
\text { інвестор }\end{array}$} & \multirow{2}{*}{ 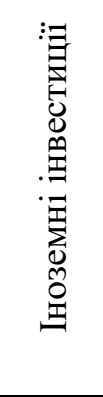 } & \multicolumn{2}{|c|}{$\begin{array}{l}\text { Зовнішня } \\
\text { торгівля }\end{array}$} & \multicolumn{2}{|c|}{ Туризм } & \multicolumn{2}{|c|}{$\begin{array}{c}\text { Міждержавна } \\
\text { міграція }\end{array}$} & \multirow{2}{*}{ 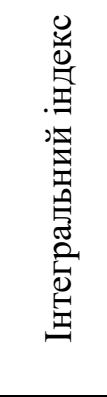 } \\
\hline & & & 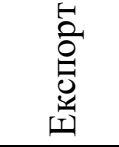 & 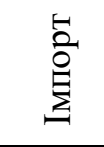 & 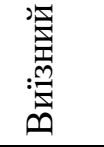 & 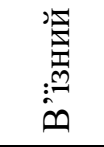 & 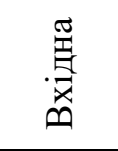 & 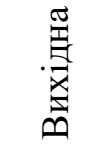 & \\
\hline Волинська & Польща & 0,161 & 0,149 & 0,131 & 0,054 & 0,266 & 0,141 & 0,115 & 0,147 \\
\hline Закарпатська & Угорщина & 0,060 & 0,506 & 0,102 & 0,040 & - & 0,052 & 0,581 & 0,223 \\
\hline Львівська & Польща & 0,147 & 0,188 & 0,251 & 0,017 & 0,415 & 0,099 & 0,137 & 0,183 \\
\hline Чернівецька & Румунія & 0,087 & 0,367 & 0,082 & 0,007 & 0,000 & 0,026 & 0,015 & 0,084 \\
\hline
\end{tabular}
$20]$.

Джерело: розраховано автором на основі регіональних служб статистики Украӥни [17-

Як бачимо 3 таблиці 1, найвищий інтегральний коефіцієнт прикордонної спеціалізації має Закарпатська область - 0,223, найнижчий Чернівецька - 0,084. 
Розглянемо тепер детальніше напрямки міжрегіональної взаємодії прикордонної співпраці досліджуваних областей.

Відтак, у Волинській області найвищий коефіцієнт прикордонної співпраці у 2019 році спостерігався у сфері в 'їного туризму (0,266 пункти), а також зовнішньої торгівлі та інвестиційної діяльності.

У Закарпатській області найвищий коефіцієнт прикордонної співпраці відзначається у напрямку «вихідного міграційного потоку» $(0,581$ пунктів), а також у сфері зовнішньої торгівлі. Зокрема, близько 51\% експорту Закарпатської області надходить саме в Угорщину.

Щодо найвищого коефіцієнту прикордонної співпраці Львівської області, то найвищий показник зафіксовано у напрямку «в'їзного туризму» $(0,415$ пунктів). Це означає, що практично $42 \%$ іноземних туристів регіону прибувають 3 прикордонної Польщі. Цілком зрозуміло, чому саме туризм вибраний пріоритетом реалізації програми прикордонного співробітництва «Україна-Польща-Білорусь». Можна говорити про залежність розвитку туристичної галузі регіону від потоку туристів 3 суміжною Польщею. Це повинно послужити основою для більш глибокого аналізу і розробки рекомендацій щодо оцінки ефективності реалізації туристичного потенціалу, а також диверсифікації туристського потоку.

Торгівля 3 Польщею також займає вагоме місце у зовнішній торгівлі області, зокрема у 2019 році частка експорту Львівської області до Польщі становила 18,8\%, а імпорту $25,1 \%$.

Найменш розвинутою в сфері прикордонної співпраці з державою-членом ЄС $€$ Чернівецька область. Найвищий коефіцієнт прикордонної співпраці області у 2019 році спостерігався у сфері зовнішньої торгівлі, зокрема експорту (0,367 пункти). Натомість найменш розвиненою сферою є туризм.

Також цікаво здійснити порівняльний аналіз динаміки прикордонної співпраці упродовж десяти років існування програм транскордонної співпраці Волинської, Закарпатської та Львівської областей (див. рис. 1).

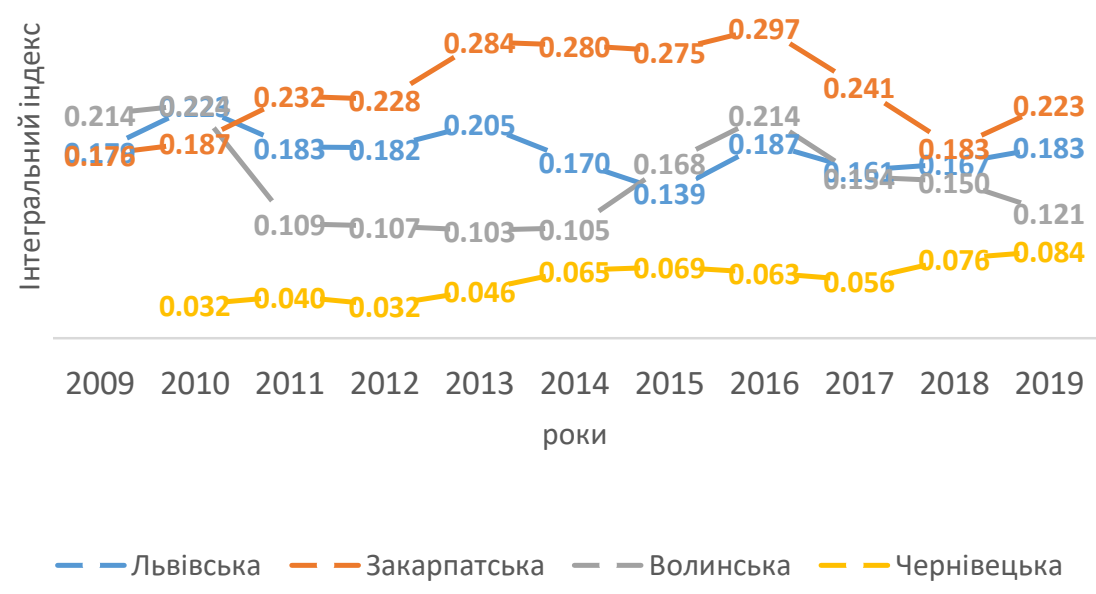

Рис. 1. Динаміка інтегрального індексу прикордонної спеціалізації Волинської, Закарпатської, Львівської та Чернівецької областей упродовж 2009-2019 років

Джерело: складено автором на основі регіональних служб статистики України [17-20].

3 рисунка 1 бачимо, прикордонна співпраця більшості досліджуваних областей відзначалася нестабільністю. Так, у Закарпатській області найвищі показники індексу прикордонної спеціалізації спостерігалися упродовж 2013-2016 років (за рахунок зростання коефіцієнта прикордонної спеціалізації експорту з 0,256 пунктів у 2012 році 
до 0,439 пунктів у 2016 році та коефіцієнта прикордонної спеціалізації міждержавного міграційного обміну з 0,331 пункти у 2012 році до 0,571 пункти у 2016 році). Загалом індекс індексу прикордонної спеціалізації Закарпатської області у 2019 році зріс на 0,048 пунктів, порівняно із 2009 роком.

На противагу Закарпатській області, індекс прикордонної спеціалізації Львівської області знижувався упродовж 2013-2015 років (за рахунок зниження коефіцієнт прикордонної спеціалізації туристичного обміну з 0,155 пунктів у 2013 році до 0,047 пунктів у 2015 році та міждержавного міграційного потоку з 0,210 пунктів у 2013 році до 0,100 у 2016 році), а у порівнянні з 2009 років зріс лише на 0,004 пункти.

Найбільший спад індексу прикордонної спеціалізації фіксуються у Волинській області (зокрема упродовж 2011-2014 років та 2017-2019 років). Відтак, індекс прикордонної спеціалізації Волинської області у 2019 році знизився на 0,094 пункти, порівняно з 2009 роком. Такий спад пов'язаний в першу чергу зі спадом інвестицій 3 Польщі (з 48\% від загального обсягу інвестицій в область у 2009 році до $16 \%$ у 2019 році).

Лише у Чернівецькій області упродовж досліджуваного періоду спостерігалося зростання коефіцієнта прикордонної співпраці (з 0,034 пунктів у 2010 році до 0,084 пунктів у 2019 році), однак сам коефіцієнт є доволі незначним.

Висновки. Таким чином, з проведеного дослідження бачимо, що інтенсивність прикордонної співпраці не $є$ стабільною. Однак, проаналізовані дані свідчать про важливість транскордонної співпраці для трьох областей - Волинської, Закарпатської та Львівської. Ефекти, виявлені в рамках пілотної оцінки прикордонній спеціалізації, можуть стати основою для більш глибокого аналізу і коригування пріоритетних напрямів регіональної політики з метою посилення позитивних ефектів міжрегіональної взаємодії прикордонних регіонів і зниження ризику можливих негативних ефектів від високого рівня прикордонної спеціалізації.

Однак, задля кращої оцінки співпраці прикордонних областей України та державчленів СС пропонуємо на регіональному рівні (обласними державними адміністраціями та відповідальними за транскордонне співробітництво управліннями, що у співпраці 3 відповідними управліннями з іншого боку кордону, головними управліннями статистики у областях) удосконалити статистичну інформацію в розрізі досліджуваних напрямків. Вважаємо за необхідне розробити спільну базу даних та налагодити моніторинг в рамках здійснення місцевого прикордонного руху (кількість виданих дозволів, частота перетину кордону, мета і тривалість перебування тощо), а також створення спільної інформаційностатистичної платформи у сфері функціонування транскордонного ринку праці (створення та оновлення на постійній основі баз даних щодо попиту на робочу силу відповідної кваліфікації зі сторони роботодавців та, відповідно, пропозицій зі сторони мешканців прикордоння, які шукають роботу; інформація щодо працевлаштування в українсько-польському прикордонні, кількості працевлаштованих, затребуваних видів економічної діяльності, терміну працевлаштування тощо). Також було б доречно вести статистику припливу іноземних інвестицій, зовнішньої торгівлі, міграційного та туристичного потоку між прикордонними областями (до прикладу, між Львівською областю та Підкарпатським воєводством).

Подальші дослідження можуть бути присвячені порівняльному аналізу коефіцієнтів прикордонної співпраці прикордонних областей України та прикордонних регіонів держав-членів $€ С$.

\section{Список бібліографічного опису}

1.Anderson, J. et al. Why study borders now? Regional and Federal Studies. 2002. No 12, Pp. 1-12.

2.Blatter, J. and Norris, C. II Introduction to the Volume: Cross-Border cooperation in Europe: Historical development, institutionalization, and contrasts with North America. Journal of Borderlands Studies. 2000. No 15.1, Pp. 14-53. 
3.Bufon, M. and Markelj, V., Regional Policies and Cross-Border Cooperation: New Challenges and New Development Models in Central Europe. Revista Româna de Geografie Politica, 2010. No. 1, May 2010, pp. 18-28.

4.Van Der Veen, A., and Boot, D.-J. Cross-border co-operation and European regional policy. Competitive European peripheries. Springer, Berlin, Heidelberg, 1995. Pp.75-94.

5.Durand, F. and Decoville, A. A multidimensional measurement of the integration between European border regions, Journal of european integration, 2019. URL https://doi.org/10.1080/07036337.2019.1657857 (дата звернення: 02.11.2020 p.).

6.Межевич Н.М., Жук Н.П. Специализации межрегиональных взаимодействий приграничных регионов и результаты пилотной оценки. Балтийский регион. 2013. №1. С. 38-52.

7.Межевич Н., Радвилавичюс Ш. Роль приграничного сотрудничества между Европейским союзом и Российской Федерацией в двусторонних и региональных программах экономического развития. Брюссель: ЕСО, 2010. 125 с.

8.Knippenberg, H., Markusse, J. "19th and 20th century borders and border regions in Europe". In Nationalising and denationalising European border regions, 1800-2000: views from geography and history, 1-19. Hans Knippenberg and Jan Markusse, eds. Dordrecht: Kluwer, 1999.

9.Varnaliy, Z.S., Vasyltsiv T.G. Factors and Ways of Cross-Border Cooperation Development of Border Regions of Ukraine, The USV Annals of Economics and Public Administration, 2016. Vol. 16, Pp. 66-71.

10. Davydenko, S., Yehorova, O. Cross-border cooperation in Ukraine: the economic aspect. Individual and Society, 2012. Vol. 15, No. 4

11. Zarichna, O. New Forms of Cross-Border Cooperation, Management, 2018. No. 2, Pp. 99-107.

12. Розвиток транскордонного співробітництва: науково-аналітична доповідь / НАН України. ДУ «Інститут регіональних досліджень імені М. І. Долішнього НАН України»; наук. редактор В.С. Кравців. Львів, 2017. 89 с.

13. Kuzmin, O., Kravchenko I. Cross-border cooperation of enterprises: essence and significance, Econtechmod. An International Quarterly Journal, 2014. Vol. 3. No. 2. Pp. 35-40.

14. Кухарська, Н.О. Транскордонне співробітництво як форма розвитку економічних відносин України на регіональному рівні / Н. О. Кухарська // Management of modern socio-economic systems Актуальні: Collective monograph / [edited by J. Žukovskis, K. Shaposhnykov]. Kaunas, Lithuania: Izdevniecība "Baltija Publishing”, 2017. Vol. 1, Pp. $263-291$. 15. Mikula N. Interterritorial and cross-border cooperation: Monograph. Lviv: IRD National Academy of Sciences of Ukraine, 2004. $395 \mathrm{p}$.

16. Мікула Н.А., Засадко В.В. Транскордонне співробітництво України в контексті євроінтеграції. URL : http://lv.niss.gov.ua/content/articles/files/ Mikyla_Zasadko_24_06-c1513.pdf. (дата звернення: 05.11.2020р.).

17. Головне управління статистики у Волинській області. URL: http:/www.lutsk.ukrstat.gov.ua/ (дата звернення: 25.08.2020).

18. Головне управління статистики у Закарпатській області. URL: http://www.uz.ukrstat.gov.ua/ (дата звернення: 25.08.2020).

19. Головне управління статистики у Львівській області. URL: https:/lv.ukrstat.gov.ua/ (дата звернення: 20.07.2020)

20. Головне управління статистики у Чернівецькій області. URL: http:/www.cv.ukrstat.gov.ua/ (дата звернення: 15.08.2020).

\section{References}

1.Anderson, J. et al. Why study borders now? Regional and Federal Studies. 2002. No 12, Pp. 1-12.

2.Blatter, J. and Norris, C. II Introduction to the Volume: Cross-Border cooperation in Europe: Historical development, institutionalization, and contrasts with North America. Journal of Borderlands Studies. 2000. No 15.1, Pp. 14-53.

3.Bufon, M. and Markelj, V., Regional Policies and Cross-Border Cooperation: New Challenges and New Development Models in Central Europe. Revista Româna de Geografie Politica, 2010. No. 1, May 2010, pp. 18-28.

4.Van Der Veen, A., and Boot, D.-J. Cross-border co-operation and European regional policy. Competitive European peripheries. Springer, Berlin, Heidelberg, 1995. Pp.75-94.

5.Durand, F. and Decoville, A. A multidimensional measurement of the integration between European border regions, Journal of european integration, 2019. URL https://doi.org/10.1080/07036337.2019.1657857 (accessed: 02.11.2020 p.).

6.Mezhevych N.M., Zhuk N.P. Spetsyalyzatsyy mezhrehyonalnыkh vzaymodeistvyi pryhranychnыkh rehyonov y rezultatы pylotnoi otsenky. Baltyiskyi rehyon. 2013. No 1. Pp. 38-52. [in Russian].

7.Mezhevych N., Radvylavychius Sh. Rol pryhranychnoho sotrudnychestva mezhdu Evropeiskym soiuzom y Rossyiskoi Federatsyei v dvustoronnykh y rehyonalnыkh prohrammakh эkonomycheskoho razvytyia. Briussel: ECO, 2010. 125 p. [in Russian].

8.Knippenberg, H., Markusse, J. "19th and 20th century borders and border regions in Europe". In Nationalising and denationalising European border regions, 1800-2000: views from geography and history, 1-19. Hans Knippenberg and Jan Markusse, eds. Dordrecht: Kluwer, 1999.

9. Varnaliy, Z.S., Vasyltsiv T.G. Factors and Ways of Cross-Border Cooperation Development of Border Regions of Ukraine, The USV Annals of Economics and Public Administration, 2016. Vol. 16, Pp. 66-71.

10. Davydenko, S., Yehorova, O. Cross-border cooperation in Ukraine: the economic aspect. Individual and Society, 2012. Vol. 15, No. 4

11. Zarichna, O. New Forms of Cross-Border Cooperation, Management, 2018. No. 2, Pp. 99-107.

12. Rozvytok transkordonnoho spivrobitnytstva: naukovo-analitychna dopovid / NAN Ukrainy. DU «Instytut rehionalnykh doslidzhen imeni M. I. Dolishnoho NAN Ukrainy»; nauk. redaktor V.S. Kravtsiv. Lviv, 2017. 89 s. [in Ukrainian].

13. Kuzmin, O., Kravchenko I. Cross-border cooperation of enterprises: essence and significance, Econtechmod. An International Quarterly Journal, 2014. Vol. 3. No. 2. Pp. 35-40.

14. Kukharska, N.O. Transkordonne spivrobitnytstvo yak forma rozvytku ekonomichnykh vidnosyn Ukrainy na rehionalnomu rivni. In: Management of modern socio-economic systems Актуальні: Collective monograph / [edited by J. Žukovskis, K. Shaposhnykov]. Kaunas, Lithuania: Izdevniecība "Baltija Publishing”, 2017. Vol. 1, Pp. 263-291. [in Ukrainian].

15. Mikula N. Interterritorial and cross-border cooperation: Monograph. Lviv: IRD National Academy of Sciences of Ukraine, 2004. $395 \mathrm{p}$. 
16. Mikula N.A., Zasadko V.V. Transkordonne spivrobitnytstvo Ukrainy $\mathrm{v}$ konteksti yevrointehratsii. URL : http://lv.niss.gov.ua/content/articles/files/ Mikyla_Zasadko_24_06-c1513.pdf. (accessed: 05.11.2020 p.) [in Ukrainian].

17. Holovne upravlinnia statystyky u Volynskii oblasti. URL: http://www.lutsk.ukrstat.gov.ua/ (accessed: 25.08.2020) [in Ukrainian].

18. Holovne upravlinnia statystyky u Zakarpatskii oblasti. URL: http://www.uz.ukrstat.gov.ua/ (accessed: 25.08.2020) [in Ukrainian].

19. Holovne upravlinnia statystyky u Lvivskii oblasti. URL: https://lv.ukrstat.gov.ua/ (accessed: 20.07.2020) [in Ukrainian]. 20. Holovne upravlinnia statystyky u Chernivetskii oblasti. URL: http://www.cv.ukrstat.gov.ua/ (accessed: 15.08.2020) [in Ukrainian].

Дата подання публікації 18.12.2020 p.

UDC 330.3, 339.9

Bobenič Hintošová A. PhD., Associate Professor Бобеніч Гінтошова А. к.е.н., доцент https://orcid.org/0000-0001-8728-6328

Bruothová M. PhD.

Бруотова М. к.е.н.

https://orcid.org/0000-0002-1116-3273

\title{
DIGITALIZATION AS A TOOL TO SUPPORT INNOVATION: A EUROPEAN PERSPECTIVE
}

\author{
University of Economics in Bratislava
}

\begin{abstract}
Implementation of information and communication technologies has changed several aspects of the economy including innovation processes and their outputs. It is generally stated that the use of information and communication technologies enhances innovation. However, the process of digitalization, especially in transforming economies, is approximately in the middle of its formation and visible effects on innovation may occur only with more developed stages of digitalization. Hence, the aim of the present paper is to investigate the relationship between the digital transformation of the economy and the innovation performance at the level of the European Union member states. For comparison purposes the European countries are divided into the particular groups according to their level of digitalization and innovation performance. The results of analysis show positive interdependence between the Summary Innovation Index and the Digital Economy and Society Index. We take into account three-year values of both indexes with one-year lag in the case of the second one, since we expect a time shift in the innovation performance induced by the development of the digital economy and society. Moreover, the digital development - innovation matrix showed that the most digitalized European countries are the most innovative ones, a vice versa. The majority of the "old" European Union member states belong to the group of digitalized innovators, with relatively high level of digitalization associated with superior innovation performance. On the other hand, for the most of the "new" European Union member states, lower levels of digitalization are associated with below-average innovation performance. Only some exemptions were detected in this regard. Hence, digitalization can be considered as a tool to foster innovation.
\end{abstract}

Key words: digitalization, innovation, the European Union

\section{ДИДЖИТАЛІЗАЦІЯ ЯК ІНСТРУМЕНТ ПІДТРИМКИ ІННОВАЦІЙ: ЄВРОПЕЙСЬКА ПЕРСПЕКТИВА}

Університет економіки в Братиславі

Впровадження інформаційно-комунікаційних технологій змінило певні аспекти економіки, включаючи інноваційні процеси та їх результати. Загалом зазначається, що використання інформаційнокомунікаційних технологій сприяє розвитку інновацій. Однак, процес диджиталізації, особливо в країнах з трансформаційною економікою, знаходиться приблизно в середині свого формування, і видимі наслідки для інновацій можуть мати місце лише на більш розвинених стадіях цифровізації. Отже, метою даної роботи є дослідити взаємозв'язок між цифровою трансформацією економіки та інноваційними показниками на рівні держав-членів Свропейського Союзу. Для порівняння європейські країни 